\title{
PROFILE OF THE ORGANIZATIONAL CULTURE IN YOUTH CLUB FOOTBALL (THE PRESENT SITUATION IN BLAGOEVGRAD REGION)
}

\author{
Trayan Popkochev, Valeri Tsvetkov
}

South-West University "Neofit Rilski," Blagoevgrad, Bulgaria

\section{OPEN ACCESS}

Submitted: 17 June 2021 Revised: 22 November 202 Accepted: 24 November 2021

ORCID iD

Trayan Popkochev https://orcid.org/0000-0003-2789-2566 Valeri Tsvetkov https://orcid.org/0000-0003-4932-4885

Cite this article as:

Popkochev, T., Tsvetkov, V. (2021).

Profile of the organizational culture in youth club football (the present situation

in Blagoevgrad region)

Journal of Applied Sports Sciences, Vol.2, pp. $77-92$.

DOI: $10.37393 / J A S S .2021 .02 .7$

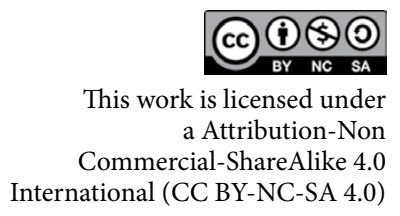

International (CC BY-NC-SA 4.0)

\begin{abstract}
The end of the crisis in Bulgarian football is discussed through the perspective of solving the problems in youth football. Although organizational culture is essential for effectiveness within organizations, few studies are related to the organizational culture in (youth) football clubs in Bulgaria.

The article aims at studying the organizational culture in three clubs from the Youth-17 League in the South-West Bulgaria Zone 1 and Zone 2.

60 players and 3 coaches participated in a survey conducted through OCAI (Cameron and Quinn). The weight of certain factors considered important for achievement in clubs was measured through dispersion analysis.

The hierarchy and clan types are predominant in the club's profiles. According to the analysis, the present state is characterized by fewer distractions than the desired state. ANOVA shows that the team success factor has the strongest influence regarding the differentiation of the clan (present state) and market (desired state) types of cultures. The competing experience factor has a lesser effect and differentiates the market and the adhocracy type of cultures (the desired state). The prospect factor differentiates between the clan and market type in the desired state.

Both groups surveyed have similar preferences for the types of organizational culture in the teams, with the "strength" of the preference criteria having higher value with the coaches.

The typical team sport profile of organizational culture is observed. Coaches can influence the sports training activities and manage the organizational culture in the clubs through the factors mentioned above when players are still young.

The study is not representative of the South-West League and Bulgaria as a whole.

Organizational culture significantly influences competing efficiency and good youth football players ' making.
\end{abstract}

Keywords: Football, Youth, Organizational culture, Organizational culture profile, Factors

\section{INTRODUCTION}

Bulgarian men's football has been in a state of ongoing crisis since the successful performance at the 1994 World Cup (BFU; Balakov, 2020; Kartunov, 2020). The lack of continuity in athlete creation is a major underlying cause of the crisis, which football players, coaches, sports leaders, and professional football club owners constantly discuss. (BFU). There is strong criticism of the ineffective recruitment policies in youth football and the development of elite professional players. (Ilchev, 2019). Crucial areas often discussed are discipline, sporting honour, responsibility to the team, players' motivation, discipline, and self-discipline (Christo Stoichkov spoke strongly about it), relationships within the team: between players, players, and coaches, dedication, etc.

Such issues are directly related to building an organizational culture. In Bulgaria, it is a 
problem that in the management documentation (Natsionalna strategia, 2011; Natsionalna programa, 2020) and many statements of football coaches and managers on organizational culture in football, its study and management is neglected, even though it has an important practical significance.

In terms of scientific research, the topic of organizational culture in sport (Slack, Parent, 2006; Girginov, 2010; Cruickshank, Collins, 2012; Wagstaff, Wylie, 2018; Maitland, Hills, Rhind, 2015) has already received serious attention in some sports (Champ et al., 2020), however, in Bulgaria it is explored neither in youth nor in professional football.

SPORTS AND ORGANIZATIONAL CULTURE

In the second half of the $20^{\text {th }}$ century, a significant integration process began between sports and sports science, on the one hand, and other scientific fields, on the other. Thus, nowadays, it is impossible to build and manage an elite sports club without researching several integrative scientific areas, such as sports medicine, sports psychology, sports sociology, sports marketing, sports management (Bill, 2009, Wagstaff, Burton-Wylie, 2018), and organizational culture. A well-established practice exists in publications of didactic nature for organizational culture in sports to be considered in the context of sports management (Hoye et al. 1, 2009). Organizational culture brings together knowledge in the fields of sports management and organization theory, sports psychology, and sports sociology, culturology. (Slack, Parent, 2006, Bill, 2009, Hoye, et al., 2009, Girginov, 2010). Organizational culture and management share a fundamental function that has both individual and social dimensions: "both strive to create order and to avoid uncertainty" (Girginov, 2010).

Despite the differences in the understand- ing of organizational culture as something that organizations are and something that, amongst other things, characterizes them, the content of the notion includes:

- "symbols, heroes, rituals, and values" shared and validated into practice (Hofstede, 2010), which function as "mental programs or...software of the mind" in organizations, ideals, and basic self-evident collective notions which influence problem-solving in a dynamic environment when adaptation to change and inner integration is required (Shain, 2002);

- Essential values (such as respect, quality, discipline, ethics, dedication, honor, justice/impartiality), beliefs, and attitudes which shape the behavior within the organization, thus turning into standards and norms of behavior in the organization (Hoye et al., 2009).

Organizational culture works to preserve the homeostasis of an organization and protect it from the impact and threats of the external environment. It influences the integration of organization members and the creating of organizational identity. Organizational culture helps regulate the behavior of organization members and the integration of newly enrolled ones. It influences goals, motivation, and results both on an individual and team level and plays a vital role in the stability, adaptability, and innovation within an organization. Its condition and functionality can be used as signals for necessary changes in the values and structure of an organization.

Girginov noted that organizational culture strongly influenced the way sports management was studied, taught, and practiced (Girginov, 2010). In modern sports, the actual management of organizational culture is one of the main practical tasks that sports psychologists, coaches, and managers must complete. The developments in that area are not simply creating organizational culture but creating an organizational culture that supports excellence 
in sports achievements. (Cruickshank, Collins, 2012).

The classification of organizational cultures varies. One of the most popular is by E. Shain (2002). In terms of its accessibility to observation and analysis, the organizational culture is observed as a three-layered formation of artifacts and symbols (1), values (2), and a most profound and complex system of underlying assumptions about people, interpersonal relationships, and truth (3). Hofstede's other authoritative interpretation is on criteria such as distance from an authority, acceptance of indeterminacy, relation to community and individuality, assertiveness (masculinity-femininity), projection of the time horizon (Sheldrake, 2001).

Adhering to the research of Cameron and Quinn (2012), in the context of this study, organizational culture is perceived as a set of values and norms that, in an institution such as a sports club, are the basis for achieving adaptation to the environment and achieving inner integrity.

The theory of Kim Cameron and Robert Quinn that organizational cultures can be classified within a system of two criteria for efficiency is used for this empirical study. The first criterion differentiates efficiency based on values such as "flexibility, personal judgment, and dynamism" from efficiency based on "stability, order, control". The second criterion is the opposition between "internal organization, integration and unity" and "external orientation, differentiation, and competition". These criteria lay the foundation for the classification of organizational culture, also known as the competing value framework (CVF). The framework consists of four elements or types of organizational culture: clan, adhocracy, market, and hierarchy. (Cameron, Quinn, 2012). The organizational culture of a particular organization is never limited to one type only; the types co-exist and complete each other, each having a different weight within the framework. (Cameron, Quinn, 2012). The balance of the four types within an organization makes up the "profile of organizational culture," i.e., their stable configuration about particular factors with significant influence on the configuration.

\section{Aims and tasks}

The concept of the empirical study lies within the framework of understanding the role of organizational culture and the interpretation of the crisis in Bulgarian football. The study focuses on the age group of 17-year-old youths. (Y-17).

The study aims to examine the three independent variables (factors) that play part in building an organizational culture within three football clubs.

The subjective opinion of 17-year-old players from three clubs on the following three variables was studied: Success of the team of the surveyed groups; Competitive experience of the surveyed persons. The three clubs differ in their team successes and the zones in which they compete.

\section{METHODOLOGY \\ Problem}

Based on the understanding of (1) the functions of organizational culture and (2) its significance in the building of sports teams and the overcoming of crises in football teams, we make the general logical assumption that at a young age, the development of football players should not be limited to sports-and-technical training but should also include building adequate organizational culture. However, this proves to be a difficult task. Definite research should be conducted regarding age and football practices to accomplish this task. Alas, in Bulgarian conditions, such studies are not 
available. The characteristics of organizational culture in the clubs of children and adolescents who are training and playing competitive soccer are not discussed and reviewed. The factors that influence the development of organizational culture are not acknowledged. Also, no studies have been conducted on the problems that arise when the 'level' of organizational culture changes, e.g., when the players change the league they play in (move to a higher level) or go into professional football.

\section{Hypotheses}

The hypotheses are built on the basic values of organizational culture, which have an internal contradiction in their integrity. This is what gives grounds for applying the OCAI tool of Cameron and Quinn.

The hypotheses subject to exploration are:

We assume that the informants in the clubs are at such age that the profile of the organizational culture is formed under the influence of the following factors: 1) the competitive experience; 2) successes of the club in matches; 3 ) the vision of the subjects about their personal sports future in the team, hence, personal perspective is an important factor in the attitudes towards organizational culture.

\section{Method}

Hypothesis testing is based on information obtained through an adapted version of OCAI - Cameron and Quinn's competing values instrument (Organizational Culture Assessment Instrument). It checks the perception of organizational culture in two modes - actual and desired state based on six criteria: 1) dominant characteristics, 2) leadership, 3) personnel management, 4) organization solder, 5) basic strategies, 6) criteria for success (Cameron and Quinn, 2012). For each criterion, four statements that correspond to the four types of organizational culture (adhocracy, market, hi- erarchy, and clan) are formulated.

Cameron and Quinn's methodology was adopted because the value characteristics of these types of organizational culture are adequate to main football features: a leading role of teamwork in the club alongside the strive for individual performance; the strive for high achievements and victories, and the strive for defending the club's name and honor; coaching decisions, responsibility in the game and authority for personal decisions and actions; dual dynamics of the competitive environment - within the club and with other clubs (Tsvetkov, 2012).

The players and coaches are participating in the survey filled-in evaluation cards. Each of the six criteria distributed 100 points among the statements related to the four types of organizational cultures studied. The survey was conducted twice. The first survey aimed to evaluate the club's organizational culture as seen at the time of the study (real state mode). The second survey assessed the desired state in three years. The desired state actually expresses the desire for change. The chosen period is shorter than the one proposed by the original methodology because of the age of the subjects and the short time they have to move to the next age group of eighteen-year-olds (Y-18).

\section{Factors}

The empirical survey is based on a model that uses the types of organizational culture as a dependent variable. Following the hypotheses, the factors tested for their influence on the attitude of the participants/informants towards the types of organizational culture in their teams are determined.

1) Success (place in ranking) of the team of the surveyed groups. Success is a result of organizational culture, but it also maintains it by being part of it. Success and victories are part of the history, the symbolic assets, and the myths of the organizational culture of the club. 
They are another name for the effectiveness of the club's play and its organizational culture. They become a factor that "returns" its influence through the attitude towards the dominant type of organizational culture and presents it diagnostically. The more the team succeeds, the more success develops and strengthens the team's climate, cohesion, goals, trust in the coach (Shaw, 2019, Honigstein, 2016).

The data about this independent variable was analyzed on a nominal club scale for the following clubs: the Pirin, Pirin 2001, and September.

2) Competitive experience of the surveyed persons. It is manifested not only in sports-and-technical improvement but also in internalized organizational culture (norms and rules, ideals and goals, beliefs, and authorities in the organization). It provides an opportunity for better knowledge and adaptation to the organizational culture and for influencing organizational culture through personal awareness, skills, achievements, contacts, personal authority. According to this factor in the analysis, all participants were divided along an interval scale into groups with competitive experience up to 3 years $(\mathrm{n}=8)$ and over three years $(\mathrm{n}=51)$.

3) Vision for a personal future career in the team. Personal prospects are essential for the attitude towards the organizational culture. If they satisfy people, they see their future in the organization and contribute to its preservation and development so that their personal future is stable and predictable. To track this factor in the analysis, the data about the entire sample was broken down on a nominal dichotomous scale into two groups: with an insecure and unclear future against a stable one and with good prospects in the team.

\section{Scope of the survey}

The research includes 60 athletes from group "adolescents -17 years of age" and the three coaches of the participants' teams. All of them were familiarized with the experiment's methodology and knew how to use it. The coaches reviewed the research inventory and gave their consent for a field study with their teams. However, they were not present during the field study itself. The survey was anonymous, and the participants who gave their consent to voluntary participation in the study were included in it, worked independently and individually, and had no contact with the other respondents. They compete for the following teams: Pirin $(n=19)$, Pirin $2001(n=17)$ and September - Simitli $(n=24)$. The mean age of the participants was over 17 years. Their competitive experience in the respective teams is between one and over three years.

The three teams compete in the regional youth group. They distinctly differ in their achievements, and this gives an opportunity to trace the influence of this factor on the organizational culture at the specified age. Their performance at the beginning of the survey (14.01.2021) was as follows:

- "Pirin", Zone 1., 19.09. - second place; 14.01.2021 - 12 matches played, third place. This is the team with the highest achievements/ results from the three teams in the survey and the one with the longest/ richest club history.

- "Pirin 2001" - Zone 2, 19.09. - sixth place; 14.01.2021 - 13 matches played, third place (Zone 1 has higher status compared to Zone 2).

- „September-Simitli” - Zone 1., 19.09. - thirteenth place; 14.01.2021 - 12 matches played, thirteenth place.

A variation of the same survey tool was used to conduct the survey with the coaches of the three teams.

The field survey with the players was conducted between the $19^{\text {th }}$ of September and the $15^{\text {th }}$ of October 2020. 


\section{Processing the results}

The results obtained from the individual cards were processed with SPSS 23. ANOVA analysis was applied to verify the hypotheses. The requirements for applying the method were met (Ganeva, 2016): a) the observations were independent. b) the size of the groups participating in the survey was approximately the same $(1: 1,18: 1,41)$; c) the factors and the variables correlated (Nikolova, 2004); d) the data were normally distributed, which was verified through the ratio of the asymmetry to the standard deviation (Table 1).

Table 1. Distribution verification results

\begin{tabular}{|c|c|c|c|c|}
\hline \multirow{2}{*}{ Groups/cultures } & Clan & Adhocracy & Market & Hierarchy \\
\hline & Skew./ StDev. & Skew./ StDev. & Skew./ StDev. & Skew./S StDev. \\
\hline Success & \multicolumn{4}{|c|}{ Real state / Desired state } \\
\hline Pirin & $.337 / .167$ & $.307 /-.124$ & $-.362 / .069$ & $-.175 / .068$ \\
\hline September & $.177 / .251$ & $.086 / .035$ & $-.028 /-.214$ & $.382 / .401$ \\
\hline Pirin 2001 & $.174 / .047$ & $.307 / .144$ & $-.073 /-.194$ & $-.010 /-.031$ \\
\hline Experience & \multicolumn{4}{|c|}{ Real state / Desired state } \\
\hline Up to 1 year & $-3.728 / .331$ & $.600 / .140$ & $-.279 / .000$ & $.000 /-.735$ \\
\hline Up to 3 years & $.273 / .116$ & $.344 / .315$ & $.206 /-.106$ & $-.171 /-.170$ \\
\hline Over 3 years & $.221 / .208$ & $.658 / .033$ & $.038 /-.020$ & $.586 /-.170$ \\
\hline Position & \multicolumn{4}{|c|}{ Real state / Desired state } \\
\hline Titular & $.195 / .086$ & $.662 / .009$ & $-.100 /-.011$ & $.609 / .073$ \\
\hline Reserve & $.350 / .425$ & $.300 / .307$ & $-.193 /-.260$ & $.051 / .622$ \\
\hline Perspective & \multicolumn{4}{|c|}{ Real state / Desired state } \\
\hline Uncertain and unclear & $.121 /-.009$ & $-.060 / .166$ & $.109 / .142$ & $-.197 / .244$ \\
\hline Stable with good perspective & $.235 / .215$ & $.664 /-.001$ & $-.114 /-.324$ & $.644 / .010$ \\
\hline
\end{tabular}

Note: Skew. and StDev. denote asymmetry and standard deviation (Skewness, Std. Deviation).

The descriptive statistics were calculated as well. Leven's test was used to verify the equality of variances (Homogeneity of variance test), at significance level $\alpha=.05$ and probability $\rho<.05$ for rejection of the null hypothesis (absence of effect). The test is independent of the assumption of normality of the distribution (Kratko ..., p. 142). The significance of the differences in the averages was checked as well. Post-hoc tests and calculation of the magnitude of the effect (Cohen's $\eta$-coefficient) were applied to evaluate the differences in the groups regarding the role of the independent variables (factors) for the dominant type of organizational culture.

\section{RESULTS}

Table 2 shows the mean and standard deviation values taken from descriptive statistics in general for the sample of organizational cultures, organized by type and in descending order. According to the "strength" indicator (Cameron, Quinn, 2012), the hierarchical type, followed by the clan one, dominated the organizational culture profile in the real state mode. The evaluation of the adhocratic type provoked the highest level of disagreement, while the clan one - the lowest. The situation in the desired state mode was quite the opposite: the clan type led as measured by the "strength" indicator, followed by the hierarchical one. The market type evoked the most 
agreement, while disagreements were mostly found with the clan type. The difference in the values of the average quantities between types taking the first and last rank in the real state mode and the desired state mode was 2.633 and 5.335, respectively. Moving towards an organizational culture profile in the future caused twice as much difference compared to the evaluation of the current profile.

Table 2. Mean values for the studied types of organizational culture by modes

\begin{tabular}{lcccc}
\hline \multirow{2}{*}{ Cultures } & \multicolumn{2}{c}{ Real state } & \multicolumn{2}{c}{ Desired state } \\
\cline { 2 - 5 } & Mean & Std. Dev. & Mean & Std. Dev. \\
\hline Hierarchy & 26.6158 & 6.809 & 28.5254 & 5.557 \\
Clan & 25.2684 & 4.901 & 24.3333 & 4.025 \\
Adhocracy & 24.0141 & 6.839 & 23.8955 & 3.658 \\
Market & 23.9831 & 4.266 & 23.1893 & 4.468 \\
\hline
\end{tabular}

The dominant types in the real state mode outlined a profile with control over the internal environment - values, such as order, hierarchy, personal or collective authority, discipline and rules, security, and consistency. (While working with his players, one of the most successful football coaches in Germany, Otmar Hitzfeld, carefully built the psychological compatibility in the team, insisted on hierarchy, leadership exhibited by one or two players, discipline, and hard work (Honigstein, 2016). Conversely, the other two types of cultures with a focus on the external environment (flexibility, adaptability, competitiveness, Table 4. search for solutions in dynamic and changing conditions) were weaker (The ordinance in both modes, verified by the Spearman rank correlation, revealed strong dependence $\left(\mathrm{r}_{\mathrm{sp}}=\right.$ .8). The market culture, which embodies individuality, was not the "strongest" but caused the least amount of disagreement among those evaluated.

The influence of the independent variables on the culture profile in both modes can be seen from the values obtained from two of the measures of the central trend - the middle and the standard deviation, shown in Table 3 and

Table 3. Mean values by factors, "real state" mode

\begin{tabular}{|c|c|c|c|c|c|}
\hline \multirow{2}{*}{ Factor } & \multirow{2}{*}{ Groups } & \multicolumn{4}{|c|}{ Cultures } \\
\hline & & Clan & Adhocracy & Market & Hierarchy \\
\hline \multirow{3}{*}{$\begin{array}{l}\text { Success } \\
\text { (ranking) }\end{array}$} & Pirin 2001 & 29.186 & 23.235 & 20.147 & 26.127 \\
\hline & September & 23.854 & 24.208 & 24.653 & 27.028 \\
\hline & Pirin & 23.454 & 24.491 & 26.713 & 26.528 \\
\hline \multirow{2}{*}{ Experience } & Up to 3 years & 25.708 & 24.896 & 21.667 & 26.875 \\
\hline & Over 3 years & 25.199 & 23.876 & 24.346 & 26.575 \\
\hline \multirow{2}{*}{ Position } & Titular & 25.509 & 23.887 & 23.899 & 26.642 \\
\hline & Reserve & 23.139 & 25.139 & 24.722 & 26.389 \\
\hline \multirow{2}{*}{ Perspective } & Uncertain and unclear & 21.5769 & 24.4487 & 26.3462 & 25.7051 \\
\hline & Stable with good perspective & 26.3116 & 23.8913 & 23.3152 & 26.8732 \\
\hline
\end{tabular}


Table 4. Mean values by factors, «desired state» mode

\begin{tabular}{llcccc}
\hline \multirow{2}{*}{ Factor } & \multicolumn{1}{c}{ Groups } & \multicolumn{4}{c}{ Cultures } \\
\cline { 3 - 6 } & Clan & Adhocracy & Market & Hierarchy \\
\hline \multirow{2}{*}{$\begin{array}{l}\text { Success } \\
\text { (ranking) }\end{array}$} & September & 31,127 & 24,559 & 19,608 & 24,706 \\
& Pirin & 28,102 & 22,361 & 25,231 & 24,306 \\
\multirow{2}{*}{ Experience } & Up to 3 years & 27 & 24,576 & 25,231 & 24,09 \\
& Over 3 years & 30,208 & 26,458 & 18,75 & 24,792 \\
\multirow{2}{*}{ Position } & Titular & 28,261 & 23,493 & 23,886 & 24,261 \\
& Reserve & 28,72 & 23,975 & 23,11 & 24,195 \\
\multirow{2}{*}{ Perspective } & Uncertain and unclear & 26,806 & 23,194 & 23,889 & 25,556 \\
& Stable with good perspective & 29,2138 & 24,2899 & 22,5870 & 23,8732 \\
\hline
\end{tabular}

The market type culture dominated the profile of the group with the best performing team based on "strength" according to the "club success" factor (the place in the ranking is the empirical indicator) in the "real state" mode. The hierarchical type led to the weaker performing team in the same zone, the clan one - for the team in the next zone. There was an equal distribution within the groups of both zones in the desired state mode - the clan type determined the profile.

Based on the success factor for both modes, ANOVA made a total of eight comparisons for the groups by culture types. Only three cases exhibited statistically significant differences (Table 5). For the "real state" mode, these were: 1) the clan type with a typical magnitude of the effect $\eta$ (interpreted using Kohen - Ganeva, 2016), 2) the market type with effect $\eta$, more significant than the typical one. In the "desired state" mode with a typical magnitude of the effect $\eta$, a statistically significant difference was observed only in the case of the market type culture.

The post-hoc Tukey HSD test at $\rho<.05$ showed a statistically significant difference in the values obtained for the averages of the culture types in teams that not only take different places in the ranking but also compete in different rank zones.

a) reality state mode:

- clan, for the groups of: a) "Pirin" and "Pirin 2001" (Mean Difference (MD) -5.733, $\rho=$ .001); b) "Pirin 2001" - “September" (MD $-5.332, \rho=.001)$;

- market, for the groups of: a) "Pirin" and "Pirin 2001" (MD - 6.56- 6, $\rho=.000) ; b)$ "Pirin 2001" and "September" (MD -4.506, $\rho=.000)$;

b) desired state mode:

- clan, for the groups of „Pirin 2001” and „Septemvri” (MD - 4.128, $\rho=.001)$; b) „Pirin 2001” against „Septemvri” (MD 5.332, $\rho=.048)$;

- market, for the groups of: a) „Pirin” and „Pirin 2001” (MD 5.623, $\rho=.000)$; b) „Pirin 2001" and "Septemvri" (MD - 4.587, $\rho=.001)$.

Based on the competitive experience factor in the real state mode, the hierarchical type was stronger and dominant in the groups with 
up to 3 years of experience and more than 3 years of experience (difference of 0.259 in favor of the former). The factor's influence was neutralized in the case of the desired state mode - the clan type of culture was the strongest in both groups (Table 4). ANOVA did not show a statistically significant difference between the culture types in the real state mode based on the experience factor. Such a difference $(\rho<$ .05 ) was observed in the other mode, but only for the adhocracy and market type of cultures (Table 4 and Table 5). The hypothesis was only partially confirmed.

For the "personal prospects" factor in the real state mode, the hierarchical and market type of culture defined the group's organizational culture profile, assessing its prospects as stable and good and the group that evaluated their prospects as uncertain and unclear (Table $3)$. For the desired state mode, the clan type was the leading culture type for both groups (Table 4). The difference in evaluating the perspectives for the clan and market types of culture was statistically significant only in the real state mode. Still, in both cases, the magnitude $\eta$ of the effect was less than the typical one (Table 5). The hypothesis was only partially confirmed.

Table 5. ANOVA-results

\begin{tabular}{llcccc}
\hline Cultures / Mode & Factor & df & F & Sig. & $\boldsymbol{\eta}$ \\
\hline Clan, Real state & Success (ranking) & 2.56 & 10.062 & .000 & .264 \\
Market, Real state & Success (ranking) & 2.56 & 16.744 & .000 & .374 \\
Market, Desired state & Success (ranking) & 2.56 & 10.575 & .000 & .274 \\
Market, Desired state & Competitive experience & 2.56 & 10.659 & .002 & .158 \\
Adhocracy, Desired state & Competitive experience & 1.57 & 4.844 & .032 & .078 \\
Clan, Real state & Perspective in the team & 2.56 & 11.1097 & .002 & .163 \\
Market, Real state & Perspective in the team & 2.56 & 5.51359 & .022 & .088 \\
\hline
\end{tabular}

Note: $\rho<.05$

The survey results obtained from the coach- the best performing team, while the clan one es (Table 6) showed that the leading types of was dominant for the team coach that performs culture for both modes were the same. The $h i$ - the worst.

erarchical type was dominant for the coach of

Table 6. Organizational cultures, coaches (No. $=3$ )

\begin{tabular}{lcccccc}
\hline \multirow{2}{*}{ Cultures } & \multicolumn{3}{c}{ Modus: Real state } & \multicolumn{3}{c}{ Modus: Desired state } \\
\cline { 2 - 7 } & Pirin & Pirin 2001 & September & Pirin & Pirin 2001 & September \\
\hline Clan & 20 & 24.16 & 32.5 & 25.83 & 22.5 & 34.16 \\
\hline Adhocracy & 23.33 & 21.66 & 20.83 & 27.5 & 23.33 & 22.5 \\
\hline Market & 22.5 & 28.33 & 19.16 & 19.16 & 29.16 & 20 \\
\hline Hierarchy & 34.16 & 26.66 & 27.5 & 27.5 & 25.83 & 25 \\
\hline
\end{tabular}




\section{DISCUSSION}

Organizational culture - general profile

Adolescence establishes a sustainable selective attitude towards the environment with its cultural values and their internalization by the individual (Kon, 1980). The results confirm that the organizational culture profile imposed in the three clubs is subject to a pronounced value attitude. The practical consequence for the coaches is that they need to know the profile of the organizational culture and the expectations thereof and consider those expectations while working on the organizational culture and personal development of the athletes.

The theoretical formulation that there is no such thing as proper organizational culture can be seen in the two models' evaluations under research. The evaluation of the organizational culture profile of the present state evokes more agreement compared to the vision of the future change. The experience, whereby the influence of the coach and the "inherited" culture is quite strong, provides the necessary confidence in assessing the present state. When choosing the desired organizational culture profile, subjective differences tend to manifest, and referring to the experience tends to be more hesitant (the data are significantly scattered).

The objectified dominant culture types in the reality mode are the reason to think that the subjects accept them as adequate to the characteristics of football and adapt to them. This is part of their socialization and sports growth in an environment with pronounced internal control and significance of achievements. Coaches apparently feel comfortable exercising authority. It provides opportunities to promote their ideas about the team and the players' personal and athletic growth. The significant dispersion in the evaluations of the leading types reminds that control over the internal environment brings its own set of risks of obsession with authoritarianism (Ilyin, 2012) with concomitant addiction among players (Lozhkin, Volyanyuk, Kolosov, 2009, 2017). Though less "powerful", the market and the adhocratic type evoke more agreement. The situation reminds of how important it is for coaches to consider the power of the real culture types.

The differences in the dispersion for the two different modes (Table 2) points to the subtlety of the balance of managing change in the organizational culture profile. Coaches are under pressure to maintain control over the internal environment (Table 6), which provides a real security and promotes openness to competitiveness, individualism, and autonomy. Achieving efficiency and improving results go "hand in hand" with effective management of the organizational culture profile given the specific conditions in the teams.

Coaches are still under pressure, which comes from the expected transition to an upper age group. They are a factor in managing this change and have resources (personal authority and institutional values and history; formal position). But managing the changes in the organizational culture profile takes place in conditions of uncertainty and the different subjective expectations of the players. Therefore, coaches need to be aware of these expectations and carefully consider their value and practical dimensions. Preparing for such a change is essential to avoid the "culture shock" that occurs when transitioning towards professional football culture and successful sports and competitive development. 


\section{Collective success - organizational cul- ture}

The successful performances of teams that make up the groups are partial confirmation that this is a factor shaping the profile or organizational culture. The fact that better efficiency (successful performances) is associated with stronger market type culture highlights the role of the acceptance of its core values. However, the market type creates tension not only among the players but also between them and the managers. This brings fatigue and affects the collective nature of the game, which leads to a desire for a shift towards clan culture. Conversely, the security and control of the environment, exhibited both by the clan and the hierarchical culture type, are "strongest" in the team that performs the worst. A similar arrangement of the types is observed in the case of the coach. It is possible that a lower rate of successful performances makes this profile more suitable for maintaining stability as a prerequisite for the eventual improvement of the rate of success.

Dialectics lies in the balance between the tension created by the aspiration for competitiveness and great results and the security which comes as a result of the control over the internal environment. Looking at such a dialectic from a phenomenological point of view, Simon Critchley notes that football is a team sport, where individuality manifests and develops itself through organizational structures and their respective cultures (Critchley, 2017).

As for the coaches, the results outline two strategies: a) security and internal control the study shows that it is relevant to teams with weaker results. It aims to maintain the internal support between players and their trust in the coach as means of improving the game effi- ciency. The other strategy is a balance between teamwork and competitiveness inside the team, which aims to make players compete for the best results. This shows that building a profile of organizational culture compatible with the goals set is just as important as focusing on sports and technical development.

\section{Experience in competitions - organizatio- nal culture}

Socio-psychological research shows that the more stable the attitude towards oneself based on experience and reflexive thinking is, the more critical the attitude towards external figures of authority is (Mayers, 2010, Ogorodova, 2013) and cultural influences. These frameworks help explain that the competitive experience factor, reality state mode in both groups (with experience up to three years and over three years) is associated with more significant influence of the hierarchical type, more pronounced in the first group (the difference in the average values was .259). The other mode exhibits a preference for change to clan type (Table 4) - security is found in the group and verified during competitions and training. However, both types are characterized with strong control over the internal environment.

The absence of statistically significant difference of the experience factor for culture types in the real state mode refers again to the leading role and complementarity of the culture types of the internal control. The gradual change of this profile can be seen in the fact that the two groups of organizational cultures in the desired state mode - market and adhocracy - connect with the age of the future changes under examination, albeit with little force. The accumulation of experience leads to a more pronounced preference towards the 
market type of culture, which advocates for values, such as individuality and competitiveness (Table 4 and Table 5).

\section{Position in the team - organizational cul-} ture

In the motivational structure of the sport, the aspiration for recognition is realized through competition. In a team sport, such as football, recognizing the player's individual contribution is reflected in the position the individual player receives during the game - e.g., starter or substitute. The competition for landing a specific position and its affirmation through its accompanying role in the team is a typical way for self-realization and self-actualization in the sport (Ogorodova, 2013). It is therefore surprising that the assumption of the importance of the position starter or substitution was not confirmed. In the specific age and institutional situation, it does not appear to be a factor that divides the sample of culture types under investigation in a statistically significant way.

The "starter-substitution" position in football is associated not only with individual accomplishments but also with the coaches' decisions (Tsvetkov, 2012). It is a typical practice for coaches to change the positions of adolescent players in the structure of the team game to find the best team and personal game solutions. Thus, they also maintain a certain degree of uncertainty, which is part of their motivation strategy. The challenge lies in the boundaries, which allow for maintaining the security-insecurity balance in athletes. If the coach's assessment regarding the individual contribution and effectiveness of a player unfairly and subjectively keeps him in an unstable position (in this case, the positions under research), this contradicts the subjective self-assessment and affects the motivation for playing and achievements (Ogorodova, 2013). It affects the judgments about the organizational culture and violates the trust in its values. Given the collective nature of football and the outlined complementarity in cultures, it is possible that might be a factor of greater importance for acceptance of culture types with reduced critical disposition compared to focusing on the role of individual achievements and rewarding those with the position in the team. This reduced critical disposition imposes a negative projection on the motivation for personal affirmation and development, rewarded by landing a position that is adequate to the individual contribution to the team. Therefore, the influence of the coach in determining the position that brings recognition ("starter") appears to be an element of the coach's strategy with dual but complementary projection: sports-and-technical development and its fostering in the adolescent football players and affirming a particular profile of organizational culture.

\section{Personal perspective - organizational culture}

The group of those assessing their prospects as uncertain and unclear usually build a profile with predominantly market type of culture and lean towards change to clan type. The reason is to be found in the understanding of reality, in which the only way to distinguish yourself is through competition. The preference for clan type is the hope to overcome the uncertainty of the competitive type of culture through support and security provided by the community. Conversely, the hierarchical type consolidates the security of the position in the present for those who see themselves stable and with good prospects. In contrast, the clan type provides 
the same security in the future (Table 3 and Table 4). The perspective factor divides the two groups with only a slightly significant effect for the clan and market type and only for the real mode, which shows the complexity of perception of the different cultural values. This is even more relevant for the hierarchical and adhocratic types of cultures, where the difference is not even statistically significant.

In terms of practice, the subjective assessment of the personal perspective does not lead to unambiguous strategies for managing the profile of the organizational culture. One of the available strategies is associated with building the profile through similar and complementary values. It probably creates fewer values and personality conflicts. The second one relies on differentiating cultures by focusing on the coaches' goals to improve the game's efficiency. It is essential to note the tension created by the support of the coaches for the targeted cultural profile and the resistance of the supporters of the one that has already been established. Experience and research show that the second strategy is more challenging to implement and is met with more resistance on the part of the players. It is also not always successful for the coach - in fact, he is often sacrificed to keep the status quo in the organizational culture.

\section{CONCLUSION}

The results show that the organizational culture in the age group under investigation is subject to evaluation and design in the future (our general logical assumption). This provides perspectives for coaches, who should not ignore its existence in their work and must also build their strategy for its consolidation and modification over time. They might also consider their strategies in terms of their play- ers' future with whom they work in the field of professional football.

The organizational culture profile in the current mode is more focused, while the visions for its future provoke more disagreements. The profile in both modes is dominated by the clan and hierarchical cultures, in which the coach's control over the internal environment is strong. They tend to be more oriented towards stability, internal cohesion, support, demands, discipline. The adhocratic and market type of culture takes a back seat. However, they are rated significantly higher by the team players that show the best results during competitions. This indicates that managing change in the organizational culture is essential for improving game efficiency and results in the competitions.

On a practical level, it is essential that organizational culture change meets resistance from the established ones. Therefore, coaches should consider its positives cautiously and, with the time perspective before them, promote the desired organizational culture change. It is also important to note that transitioning towards competitions in higher age groups is associated with enhanced game efficiency requirements, which should come with an adequate organizational culture. This could be a severe motive in the coach's work with his athletes.

Coaches are more confident in responding to the different types of organizational culture in the two modes and change only their strength, which in turn provides for better stability of their position. They encounter an organizational culture profile that is typical for a team sport and have a wide range of opportunities to influence the training activity through the factors indicated above, thus guiding the 
organizational culture in the clubs from early adolescent age while still meeting the expectations of the athletes. It is always important to consider that organizational culture is a factor that carries the risk of suppressing the expressions of individualities. To the extent that the personality-organizational culture contradiction is a factor in the development of the last, this has the risk of rigidity of the same when it might be time for changes in the organizational culture.

\section{REFERENCES}

Balakov, Kr. (n.d.) Balgarskiyat futbol e v golyama i logichna kriza // Балъков, Кр. Българският футбол е в голяма и логична криза. Available at: http://www.balakov.bg/bg/article/9/българският-футбол-е-в-голяма-илогична-криза.html (Accessed 07.12.2020)

BFS. (n.d.). Vizia za badeshteto 2018-2022 // БФС. Визия за бъдещето 2018-2022. Available at: https://bfunion.bg/uploads/import/files/Vizia_Za_Badeshteto_opt.pdf (Accessed 07.12.2020)

Bill, K. (ed.) (2009). Sport Management, Padstow

Champ, Fr. M. M. S. Nesti, N. J. Ronkainen, D. A. Tod, M. A. Littlewood (2020). An Exploration of the Experiences of Elite Youth Footballers: The Impact of Organizational Culture, Journal of Applied Sport Psychology, Vol. 32, N 2, pp. 146-167

Critchley, S. (2017). O chem myi dumaem, kogda dumaem o futbole, Azbuka-Attikus, Moskva // Кричли, С. (2017). О чем мы думаем, когда думаем о футболе, Азбука-Аттикус, Москва

Cruickshank, A., Collins, D. (2012). Culture Change in Elite Sport Performance Teams: Examining and Advancing Effecti- veness in the New Era, Journal of Applied Sport Psychology, 24:3, pp. 338-355, doi: 10.1080/10413200.2011.650819

Ganeva, Z. (2016). Da preotkriem statistikata s IBM SPSS Statistics, Selestra, Sofia // Ганева, 3. (2016). Да преоткрием статистиката с IBM SPSS Statistics, Selestra. София

Girginov, V. (2010). Culture and the Study of Sport Management, European Sport Management Quarterly, September, Vol. 10, No. 4, pp. 397-417

Hofstede, G., Hofstede, G. J., Minkov, M. (2010). Cultures and Organizations. Software of the mind. Intercultural Cooperation and Its Importance for Survival. McGraw Hill.

Honigsteyn, R. (2016). Nemetskaya mashina futbol, Esmo, Moskva // Хонигстейн, Р. (2016). Немецкая машина футбол, Эсмо, Москва

Hoye, R. et al. (2009). Sport Management. Principles and Applications. Oxford. London

Ilchev, I. (2019). Kakvo kutsa v balgarskia detsko-yunosheski futbol! Prochitat na edin mlad trenyor, ot malak chasten klub. // Илчев, Илиян (2019). Какво куца в българския детско-юношески футбол! Прочитьт на един млад треньор от мальк частен клуб. Available at: http://fcsinitekamuni.com/2020/01/05/акво-куца-в-българскиядетско-юношес/ (Accessed 07.12.2020)

Ilin, E. P. (2012). Psihologiya sporta, SPb., Piter // Ильин, Е. П. (2012). Психология cnорта, СПб., Питер

Cameron, K., Quinn, R. (2012). Diagnostika i promyana na organizatsionnata kultura, Klasika i stil, Sofia // Камерън, К., Куин, Р. (2012). Диагностика и промяна на организационната култура, Класика и стил, София

Kartunov, B. (2020). Bulgaria prodalzhi 
propadaneto si v ranglistata na FIFA, Dnevnik, 22 oktomvri. // Къртунов, Б. (2020). България продължи пропадането си в ранглистата на ФИФА, Дневник, 22 октомври. Available at: https://www.dnevnik.bg/ sport/2020/10/22/4130135_bulgariia_produlji_propadaneto_si_v_ranglistata_na_fifa/ (Accessed 14.12.2020)

Kon, I. (1980). Psihologiya starsheklasnika, Prosveschenie, Moskva // Кон, И. (1980). Психология старшекласника, Просвещение, Москва

Kratko rakovodstvo za rabota s SPSS. (n.d.) // Кратко ръководство за работа с SPSS. (n.d.) Available at: http://ebox.nbu.bg/ statmethods/Base\%20Guide/Bulgarian/SPSS. pdf (Accessed 06.12.2020)

Lozhkin G., N. Volyanyuk, Yu., Kolosov, A. (2009). Vlast trenera i zavisimost sportsmena (Statya 1), Sportivnyiy psiholog, 1(16), pp. 13-19 // Ложкин Г., Волянюк, Н., Колосов, А. (2009). Власть тренера и зависимость спортсмена, Спортивный психолог, 1(16), pp. 13-19

Lozhkin G., N. Volyanyuk, Yu., Kolosov, A. (2017). Vlast trenera i zavisimost sportsmena, Sportivnyiy psiholog, Statya 2 3(46), pp. 27-36 // Ложкин Г., Волянюк, Н., Колосов, А. (2017). Власть тренера и зависимость спортсмена, Спортивный психолог, 3(46), pp. 27-36

Maitland A., Hills, L. A., Rhind. D. J. (2015). Organizational culture in sport - A systematic review, Sport Management Review, Vol. 18, N 4, 501-516

Mayers, D. (2010). Sotsialnaya psihologiya, Piter, SpB //Майерс, Д. (2010). Социальная психология, Питер, СпБ

Natsionalna programa za razvitie na fizicheskoto vazpitanie i sporta 2018-2020 g. (n.d.)
// Национална програма за развитие на физическото възпитание и спорта 2018-2020 г. (n.d.) Available at: http://mpes.government. bg/Documents/Documents/Strategii/2020/ Plan_Izpalnenie_NSM_2010-2020_za2020_ Institucii.xls (Accessed 07.12.2020)

Natsionalna strategia za razvitie na fizicheskoto vazpitanie i sporta $\mathrm{v}$ republika Bulgaria 2012 - 2022. (n.d.) 41-o Narodno sabranie, 24 noemvri 2011 g. // Национална стратегия за развитие на физическото възпитание и спорта в република България 2012 - 2022. (n.d.) 41-о Народно събрание, 24 ноември 2011 г.

Nikolova, N. (2004). Statistika, Obshta teoria, UI „Neofit Rilski”, Blagoevgrad // Николова, Н. (2004). Статистика, Общза теория, УИ „Неофит Рилски”, Благоевград

Ogorodova, T. V. (2013). Psihologiya sporta, YarGU, Yaroslavl // Огородова, Т. В. (2013). Психология спорта, ЯрГУ, Ярославль

Shaw, C. (2019). Pep Lijnders' message: „We've conquered Europe, but we're not going to stop". Available at:https://www.liverpoolfc.com/news/first-team/352842-pep-lijnders-message-liverpool-champions-league (Accessed 07.12.2020)

Shayn, E. (2002). Organizatsionnaya kultura $i$ liderstvo. Postroenie. Evolyutsiya. Sovershenstvovanie. Piter, Sankt-Peterburg // Шейн, Э. (2002). Организационная культура и лидерство. Построение. Эволючия. Совершенствование. Питер, СанктПетербург

Sheldrake, J. (2001). Teoria menedzhmenta: ot teylorizma do yaponizatsii. Piter, Sankt-Peterburg // Щелдрейк, Д. (2001). Теория менеджмента: от тейлоризма до японизации. Питер, Санкт-Петербург 
Slack, T., Parent, M. М. (2006). Under- Благоевград

standing sport organizations: the application Wagstaff, C., Wylie, S.B. (2018). Organiof organization theory. Human Kinetics, Leeds zational culture in sport: A conceptual, defi-

Tsvetkov, V. (2012). (2012). Futbolat $v$ nitional and methodological review, Sport \& uchilishte, Izd. YuZU „Neofit Rilski”, Bla- Exercise Psychology Review, Vol. 14 No. 1, pp. goevgrad // Цветков, В. (2012). Футбольт 32-52

в училище, Изд. ЮЗУ „Неофит Рилски”,

\section{Corresponding author:}

Trayan Popkochev

Pedagogy department

South-West University "Neofit Rilski"

Blagoevgrad, Bulgaria

E-mail:popkochev@outlook.com 